\title{
DUSP3 wt Allele
}

National Cancer Institute

\section{Source}

National Cancer Institute. DUSP3 wt Allele. NCI Thesaurus. Code C49418.

Human DUSP3 wild-type allele is located with $17 q 21$ and is approximately $13 \mathrm{~kb}$ in length.

This allele, which encodes dual specificity protein phosphatase 3 protein, plays a role in the dephosphorylation of protein-tyrosine phosphates, protein-serine phosphates and phosphoproteins. 